A DISSONANCE OF DISCOURSES: LITERARY THEORY, IDEOLOGY, AND TRANSLATION IN MO YAN AND CHINESE LITERARY STUDIES

\title{
Lucas Klein
}

\section{ABSTRACT}

Mo Yan's 2012 Nobel Prize for Literature quickly turned into the most controversial international literary prize of recent memory. The controversy took place largely in English, and largely on the American Internet, where as much as Mo Yan was honored as being an important literary voice from a country whose contemporary cultural products are often neglected, he was criticized for supporting the Chinese Communist Party and its government. Defenders have pointed out that the politics in his fiction are neither as simple nor as straightforward as his party membership might otherwise indicate, but critics have said he writes a "daft hilarity" in a "diseased language," calling his works in translation "superior to the original in their aesthetic unity and sureness." Taking a detailed look at the controversy and debate, I examine the theoretical assumptions and stakes at work in the reading of Mo Yan and his Nobel, with attention to their ideological underpinnings, followed with a discussion on the importance of considering translation and the relationship between literary reading and politics. I close with a look toward a broadly applicable model of internationalist reading I call translational.

KEYwords: Nobel prize, Chinese literature, literary theory, translation, Mo Yan

In 2004, then-Princeton professor of Chinese Perry Link reviewed a book by a then-associate professor of Chinese at Yale: "Laughlin writes in the fashionable language of contemporary Western academe," he suggested 
of Charles Laughlin's Chinese Reportage. Link not only criticized literary theoretical "verbiage" as "often unclear or unnecessary," he questioned its applicability to Chinese literary studies at all: "On prisons, for example, he quotes Michel Foucault.... [but] the common pattern in China has been to organize prisoners to watch one another-nearly the opposite of what Foucault describes." Moreover, "Laughlin's 'theoretical' language is entirely Western-based; he does not look into Chinese theories of literature ... Modish anti-hegemonism turns out to be the latest Western hegemonism." 1

In a response sent to the Modern Chinese Literature and Culture distribution list, Laughlin defended his points and offered examples of moments he found Link to be misreading, or indeed misquoting. He also recollected his responses to key moments in Link's career: "When Perry Link first began to decry the baleful influence of 'theory' on modern Chinese literary studies a dozen years ago ... I was not sure I understood what the big deal was. This is no longer the age of 'China hands.' I thought those of us with degrees in Chinese literature were engaged in the study of literature.... These methods, concepts, and the intellectual trends to which they sometimes adhere may not all be equally welcome, but I believe those who would engage in the study of literature - yes, even Chinese literature — should at least gain some degree of facility with them." 2

In late 2004, this may have been the last skirmish in the "theory wars" of Chinese literary studies, a debate that had crescendoed in the early nineties (later than similar "wars" in other academic disciplines) and whose opposing forces divided largely generationally. By now, another decade later, the arguments of the younger generation have turned into plain common sense, and any erstwhile resistance to theory is seen as another iteration of theory itself, even, and especially, in modern Chinese literature. ${ }^{3}$ One instance of the value of theory, particularly relating to questions of ideology and discourse, is highlighted when literature appears in international circulation, in translation, and with international prizes. Indeed, in the debates following the honoring of Chinese novelist Mo Yan (莫言) (b. I955, penname of Guan Moye [管谟业]) with the 20I2 Nobel Prize for Literature, we see the inextricability of questions of literary theory as they pertain to the reading of literature from China. Coincidentally, it is Link and Laughlin-along with a younger scholar, Anna Sun-who have squared off in the new theoretical debate. Looking at this instance of literature in the world, I will examine the theoretical assumptions and stakes at work in the reading of Mo Yan and his Nobel, with attention to their ideological underpinnings, before making a point about the importance of considering translation amidst the relationship between literary reading and politics. 
At stake is the role of translation in working toward non-ethnocentric representations of China and Chinese literature. In other words, an important aspect to the representation of Chinese literature is the representation of translation, both of translation from Chinese and of the international or translational work that Chinese literature performs as it draws from and represents other cultures and literatures. My argument is that against the ideologically simplifying representations of Mo Yan, attention to translation both of and in his works can offer a theoretically and politically productive representation of China, its literature, and its interactions with, not opposition to, the rest of the world.

\section{The Politics of Not Reading and Checking the Nerws}

The arguments that the Nobel has spawned demonstrate that we are not in what Terry Eagleton calls After Theory, nor are we dealing with what he lays out in Literary Theory: An Introduction, with "isms" and schools succeeding each other in chronological progression. ${ }^{4}$ Rather, we live in what Jonathan Culler presents in Literary Theory: A Very Short Introduction, with questions on how to read engaging each other in an endlessly contemporary debate. ${ }^{5}$ In terms of authorial intent, for instance, we can follow "The Intentional Fallacy" and assume that the text itself is the only proper embodiment of what the author was trying to say, or agree with Roland Barthes that "The Death of the Author" constitutes the birth of the reader. ${ }^{6}$ Or we can see, with Foucault, the author as a function serving to limit meaning. ${ }^{7}$ And if we are interested in unlimited meaning, we can understand Derrida's Il n'y a pas de hors-texte as allowing for the validity of an author's presentation of his own work, or that the author's statements must also be subject to critical reading. ${ }^{8}$ Not that we need such theoretical argumentation about indeterminacy of meaning: meaning is indeterminate simply because the same text will mean different things to different people at different times, and determining or asserting one person's meaning over another's must take place extra-textually. "Normally, we assume that meaning implies intent," Perry Link writes, yet words may nonetheless be used in ways where neither the instigator nor the recipient is "conscious of the word's role in conveying the meaning." But if textuality can extend across the historical context of literary production and consumption, what about the politics or ethics of the text when the author has made his political and moral standpoints clear? All possibilities seem to be on the table at once. 
One possibility is that context and assumptions of authorial position have so overdetermined judgment that reading the literature in question is no longer necessary for coming up with a stance on ethics. This seems to be behind Mo Yan's emergence as the most controversial Nobel Literature Laureate in recent memory. ${ }^{10}$ When Salman Rushdie, for instance, calls Mo Yan "a patsy of the régime," he shows no hint of having read Mo Yan. ${ }^{11}$ Interestingly, when Iran's Ayatollah Khomeini sentenced Rushdie to death for The Satanic Verses, Rushdie commented, "I doubt very much Khomeini or anyone else in Iran has read the book" (he was probably right; "the name 'Satanic verses' is an invention of Igth century British Orientalists," Eliot Weinberger explains, but the title was mistranslated in Arabic and its cognate languages as Al-Ayat ash-Shaytaniya, "with shaytan meaning Satan, and ayat meaning specifically the 'verses of the Quran.' As the phrase 'Satantic verses' is completely unknown in the Muslim world, the title, then, implied the ultimate blasphemy: that the entire Quran was composed by Satan"). ${ }^{12}$ Rushdie called Mo Yan a patsy in response to a statement comparing censorship to security checks: "Airport security exists to guard us against terrorist attacks," Rushdie wrote later. "Thus Mo Yan was making a moral equivalence between dissident literature and terrorism. That was and is objectionable, and I do not hesitate to condemn it."13

To me, Mo Yan's remarks sound like they come from a privileged yet all the same disempowered member of a society governed by an authoritarian regime. Rather than come to terms with his own complicity in the regime's authoritarianism, he makes folksy gestures toward accepting a reality others more resolute than him might oppose. Despite being a well-regarded novelist, Mo Yan is not, or does not style himself as, an intellectual in the Chinese context; sophisticated as he is as a storyteller, in his Nobel acceptance speech he mentions that his formal schooling ended after primary school, with his literary education in the People's Liberation Army Cultural Academy and his master's in creative writing from the Lu Xun Literary Institute and Beijing Normal University less important to his identity. Remarks that present government control in terms of airport security deserve, in my mind, not so much condemnation as patient explanation of where such facile analogies lead. Indeed, condemnation from Rushdie and others, who seem unable to imagine a literary writer who is not an intellectual, reveals a double-bind: on the one hand Mo Yan is a "patsy," on the other hand an author whose opinions must therefore reflect the methodological contemplations of a member of the intelligentsia. Nor do the double standards stop there: translator Brendan O'Kane pointed this out when he blogged, "T.S. Eliot was a stone-cold anti-semite. Ezra Pound was a fascist-sympathizer who 
spent the end of WWII in a cage. Roald Dahl was mean to just about everybody." If we can accept these writers as "flawed men, men who were subject to all of the limitations of their condition," O'Kane continues, "then it seems grossly unfair to condemn Mo Yan for the lesser sin of keeping his head down." ${ }^{14}$ Not that we need to go as far back as Eliot, Pound, and Dahl to see a double standard at work in criticizing Mo Yan for his politics: I do not remember suggestions that the Swedish Academy was endorsing colonialism in rewarding V. S. Naipaul in 200I, or that Mario Vargas Llosa's neoliberalism made his Nobel in 2010 a travesty. ${ }^{15}$ Of course, for all Naipaul's and Vargas Llosa's politics may be problematic or distasteful to many, they have not let those politics impinge upon the literature itself, as Mo Yan is claimed to have done. But also, Eliot, Pound, Dahl, and Naipaul are writers in English, and Vargas Llosa speaks English fluently as well, having lived for long periods in London; a difference between them and Mo Yan, then, is that neither translation nor the Anglophone imagination of the countries of these writers' origin impedes on our understanding of the ethics of the literature as much as it does with Mo Yan's Chinese and his China.

Indeed, the ways translation both reduplicates and yet also complicates how our discursive formation of China inscribes itself within our understanding of Mo Yan are worth considering. His alleged comparison of censorship to airport security came during a forum in Stockholm days before his Nobel acceptance speech, answering a question about censorship with an anecdote having to go through security checks in airports; The Guardian reported this as Mo Yan calling censorship "a must." ${ }^{16}$ Chinese-raised American novelist Yiyun $\mathrm{Li}$ (李翊云) has explained that this remark was “viewed as witty in the Chinese media and a blunder in the west," but she did not explain that the key word in the interrogator's question, "censorship," was translated not as shencha (审查) but jiancha (检查), closer to “check” than “to censor," and hence related to "security checks" at embassies and airports. ${ }^{17}$ Furthermore biyao de (必要的), like English "must," is ambiguous; as I read it, his statement wo xiang zhexie jiancha shi biyao de (我想这些检查是必要的) means not that he finds checks necessary but inevitable. I translate the rest of his sentence, about “checks on the news" (新闻检查) and not about censorship of literature, "while I've never praised the system of checks on the news, I imagine checks on the news exist in every country in the world” (我从 来没有赞美过新闻检查这种制度, 但是我也认为新闻检查在世界上 每个国家都是存在的). It is another irony that Rushdie reiterates such mistranslation-wrought confusion in his condemnation of Mo Yan, since the Khomeini's condemnation of The Satanic Verses was itself based on a mistranslation. 


\section{Political Reading and the Morphology of Consciousness}

Not reading, it turns out, is as important as reading is to our discursive formation of China: a recent Words Without Borders issue on "Banned Chinese Writers," for instance, extends a Cold War-era binary opposition vis-à-vis China with the implication that the non-banned have nothing valuable to say, since they must not be able to critique a system that does not ban them; it puts borders back in Words Without Borders. ${ }^{18}$ Could the act of reading take these borders down? This seems to be the stakes of Mo Yan's appeal in his Nobel acceptance speech, that "For a writer, the best way to speak is by writing” (对一个作家来说, 最好的说话方式是写作). ${ }^{19} \mathrm{In}$ that case, Anna Sun's article "The Diseased Language of Mo Yan" should be a relief for its attempt to buck the reductive view and offer a nuanced reading. Sun explains,

Mo Yan is a prolific writer who is a household name in China; his novels sell hundreds of thousands of copies ... Politically, Mo Yan is clearly a writer with a strong social conscience, although he has not been a dissident; he is unafraid to satirize contemporary Chinese reality in his novels, and he is wryly conscious of the game of political negotiation he has to play with the state, sometimes setting his stinging stories not in the socialist China but in the pre-revolutionary past. ${ }^{20}$

So indeed, "Why the discontent?"21

Ideology and its discourses form the basis for Sun's critique of Mo Yan, constituting what she calls the "disease" of his language in its dependence on Mao-ti (毛体), or "Mao-style." 2 A "product of the aesthetic ideologies of Socialist China," Sun defines this as "a particular language and sensibility of writing promoted by Mao in the beginning of the revolution," and describes elsewhere as "resolutely pedestrian, apart from its hyperbolic political vocabulary." ${ }^{23}$ In other words, the "Mao-ti" is a discourse, or use of language, imbued with Maoist ideology, shaping the forms and content of Chinese literature, leaving writers unable to "speak truth to power in a language free of the scars of the revolution itself." ${ }^{24}$

While the word discourse does not appear in her article, and she uses "ideology" only once, these notions underpin her definition of "Mao-ti" and her holding Mo Yan accountable for his fiction's development from and dependence on its discursive formations. Sun, whose website tells that she teaches French Social Theory, puts them to deft, though unspoken, use in her review, as "it is in discourse," as Foucault phrased it, "that power 
and knowledge are joined together." ${ }^{25}$ Since ideology as a term gets thrown about differently in different contexts, I understand it through translation: in Chinese, ideology is yishixingtai (意识形态), or the morphology (xingtai [形态]) that allows for consciousness (yishi [意识]). In Sun's case, then, her consciousness of Mo Yan is made possible by her investment in an ideological representation of China, which is a China produced in part by contemporary American discourse about it.

Such notions of ideology and discourse can help explain the behavior of someone like Mo Yan and his investment in, and loyalty to, the Chinese Communist Party. His vice-presidency in the Chinese Writers' Association (中国作家协会), for instance, may be one of the roots of his ideological buy-in to the Chinese system: after a revolution fought in part against an economy in which writers and cultural workers saw themselves as underpaid and exploited, the CWA was established to guarantee novelists, poets, and others a living wage and social benefits. Based on Lenin's call for the temporary "use of the instruments, resources, and methods of state power against the exploiters, just as the temporary dictatorship of the oppressed class is necessary for the abolition of classes," the CWA would become part of the socialist state structure into which everything else was being incorporated, so as to be free from the inherent conflicts of capitalism. ${ }^{26}$ From our point of view we can see the dangers implicit in state employment of writers, and one Chinese literary historian has called it "a direct 'inheritance' from the methods by which Stalin and Zhdanov controlled the literary and arts circles in the Soviet Union during the 1940s. ${ }^{27}$ But compared with the current US system in which writers either have to rely on the market's definition of saleable literature or else find day jobs (as part-timers in universities, for example, which may not provide sufficient health coverage), we can understand some of its attraction. ${ }^{28}$ Mo Yan, for one, has said plainly that his salary comes from the Ministry of Culture, and his "social and health insurance from them too ... without a position, I can't afford to get sick in China” (我在中 国文化部艺术研究院工作有一份工资 ...... 享受福利医疗 ...... 在中国 如果没有职业, 生病我治不起啊). ${ }^{29}$ Insofar as the Writers' Association is inscribed within the state system, it provides a vantage point for its members to see the Chinese state as supportive, rather than oppressive.

The Chinese Writers' Association, then, is what Louis Althusser named an "ideological state apparatus," calling on its members to support the Association and by extension the Chinese state via interpellation. ${ }^{30}$ Ideology and discourse have not only enjoyed fruitful afterlives in literary scholarship, they also impact the reading and writing about cultural others (as Sun no doubt also knows; she teaches another course called "Knowledge of the Other: Journey to the East"). My argument is that much of the discussion of Mo Yan's 
Nobel participates in the same ideologically reductive framework of China as has been going on for a long time. I will then draw on my elaboration of this point to make a larger conclusion about the roles and relationship between literary reading and politics, particularly in light of translation.

Interestingly, the history of writing about the People's Republic of China in the United States reveals a remarkably literary enterprise, with experts interpreting signs and signals and reading between the proverbial lines of official statements and pronouncements to get at the truth of the authorial intent behind Chinese existence. Much of this is inscribed within the discursive knowledge production of the Cold War. James Angleton, counterintelligence chief at the CIA from I954 to 1975 (and inspiration for the 2006 film The Good Shepherd), was a graduate of Yale's English department who, as Eliot Weinberger puts it, "believed that those trained in the New Criticism, with its seven types of ambiguity, were particularly suited to the interpretation of intelligence data." ${ }^{11}$ Kremlinology, too, involved literary close-readings of what information could be gleaned from behind the iron curtain, which led to Pekingology, the reading of the court politics in Zhongnanhai, the seat of government in the Chinese capital. A deconstructive reading of the term Pekingology would mention the signification of a cabal of Hong Kong-based "China watchers" mired in logocentric faith in their ability to produce stable knowledge of the country into which they were "peeking." But criticism and critique of the ideology and discursive practices of academics studying China is not new: James Peck pointed out over forty years ago how the work of American China experts "reinforced, at times deepened, the ideological justifications that support America's role in Asia and her attitudes toward China"-attitudes defined by a view of China as having, in the words of the "father of containment," US ambassador George Kennan, "fallen into the hands of a group of embittered fanatics ... consumed with ambition to extend to further areas of Asia the dictatorial authority they now wield over the Chinese people themselves." ${ }^{2}$ In other words, the Pekingologists joined American foreign policy strategists in a project of demonizing and containing China through the knowledge about their object they produced.

This is not to suggest that Sun believes China should be contained, though at any rate the terms of knowledge produced about China have changed since before Richard Nixon's visit. She does, however, contain Chinese culture within an American standard, valorizing what coheres with the association of creative writing and political liberalism taken as a given in America, and denigrating what does not:

unlike the great novelists who grapple with the harsher side of the human condition-Dickens, Hardy, and Faulkner, for example-Mo Yan's 
work lacks something important which these authors have, although it is seldom spoken of: aesthetic conviction. The aesthetic power of these authors is the torch that illuminates for us the dark and painful truth of humanity. The effect of Mo Yan's work is not illumination through skilled and controlled exploitation, but disorientation and frustration due to his lack of coherent aesthetic consideration. ${ }^{33}$

I would have thought readers in China would know better, that they would be able to accommodate more complexity, or that, aware of the history of conceptualizations of China as "the sick man of Asia" (东亚病夫) since the late nineteenth century, they would be circumspect about what they called "diseased." It's interesting to note, however, that China-as-produced knowledge can wield power over discourse about China even when the writer in question was not raised in the capitalist West. ${ }^{34}$

Sun's ideological acceptance of universalist notions comes clear in her general statements on literature, pronounced as if trans-historical judgments could apply: "The highest calling of the writer is to be moral without being moralistic," she writes in the final paragraph, "and to write with an aesthetic sensibility that is constitutive of his or her moral commitment." Her implication is that Maoist China was moralistic and yet immoral. The problem is that, for Mao and China from 1949 to the I980s, such humanistic views of literature and society would have been read as contaminated by bourgeois ideology, or the way the capitalist class convinced the peasantry and proletariat that what was good for capitalism would serve their interests as workers, as well.

\section{Chinese Audiences and the Quest for Universality}

Going too far in the denunciation of claims of universal morality as bourgeois ideology ends with the proscriptions and prescriptions of Mao's "Yan'an Talks on Literature and Art” (在延安文艺座谈会上的讲话), which Sun calls "Mo Yan's education" and his "genuine attachment" to a literature valuable only as propaganda for the revolution. ${ }^{35}$ This is the moment to turn to Perry Link, who noted in '93 that "After escaping into critical theory, [we] find that some of its terms come from European Marxists who were indirectly influenced by Mao ... a serious problem arises of how to situate two Maoisms within a single worldview." ${ }^{36}$ Despite his unwillingness to engage in literary theory, Link clearly sees Maoism not only as a political system, but a discursive or ideological one as well. This view of Maoism underpins Link's treatment of 
Mo Yan, raising for him the question of "how and to what extent a writer's immersion in, and adjustment to, an authoritarian political regime affects what he or she writes." ${ }^{37}$ Describing fictional treatments of China's real history, Link explains, "Today's Communist leaders, worried that their power could suffer by association with these Maoist disasters, declare the topics 'sensitive' and largely off-limits for state-sponsored writers." Yet Mo Yan has been part of what Link calls the "fashion in Chinese fiction" of "rewriting history," which "holds great interest for readers who are still struggling to confront the question of 'what happened?' during and after the country's Maoist spasm." Lest anyone think Mo Yan brave for broaching the topic of the Maoist period, even or especially as a state-sponsored writer, Link adds, "Mo Yan's solution (and he is not alone here) has been to invoke a kind of daft hilarity when treating 'sensitive' events." For Link, the "daft hilarity" leaves out literature's responsibility to ethics: "Mo Yan has great fun with the craziness but leaves out the disaster," he writes.

Link is certainly right in noticing that Mo Yan is not alone amongst Chinese cultural figures in laughing to keep from crying about their country's recent history (anyone familiar with contemporary Chinese art might see a similar tendency in the “Cynical Realism" of Fang Lijun [方力钧] [b. 1963] and Yue Minjun [岳敏君] [b. 1962]). For Link, this coheres too easily with "the regime's point of view," that "this mode of writing is useful not just because it diverts a square look at history but because of its function as a safety valve ... For the regime, to treat them as jokes might be better than banning them outright." While this is also true, it leaves a very limited role for nuance or subtlety in the text: can literature take an implicit stand against the government it was written under, even if it owes its existence in part to the confluences of political policy? And if literature is so totally commanded by its political circumstances, can it have any social purpose at all? Does anything change when the writing in question is read outside the immediate context of its initial publication? Is the writer's only way to be "moral without being moralistic," in Sun's phrase, to write for the overthrow of a dictatorship? Whereas in 2000 Link wrote, "The creativity of readers and audiences in adapting literature to their own uses was always present, even during the high tide of Maoism," he refuses the same flexibility to Mo Yan. ${ }^{38}$ Here, Link's answers to these questions seem overdetermined by his standpoint toward Maoism.

Link describes Mo Yan as a writer unambiguously "inside the system.” Comparing him to his "outside the system" counterpart, imprisoned 2010 Nobel Peace Prizewinner Liu Xiaobo (刘晓波) (b. 1955), Link reveals the basis and bias of his own discursive regime. Saying "It would be wrong for 
spectators like you and me, who enjoy the comfort of distance, to demand that Mo Yan risk all and be another Liu Xiaobo," Link comes off as more aware of his own ideological standpoint than does Anna Sun. Nevertheless, in response to Mo Yan's statement of hope that Liu Xiaobo "get his freedom in good health as soon as possible," Link wonders, with no evidence whatsoever, "Was Mo Yan's 'in good health' phrase something that Chinese authorities had supplied to him, perhaps to prepare the way in international opinion for Liu Xiaobo's 'seeking medical treatment abroad'?" ${ }^{39}$ (So far, this has not happened.) Later, Link flatly states, "I have never been a handmaiden to U.S. power"; such speculative decryption, however, demonstrates that the methods of Pekingology, in which the various statements and pronouncements coming out of China are deciphered as if they could reveal a stable sense of what is truly going on within the central authority, have not expired. ${ }^{40}$

In an online article titled "What Mo Yan's Detractors Get Wrong," Charles Laughlin responds to both Anna Sun and Perry Link. Though he has earlier argued in favor of applying literary theory to Chinese literature, he does not indulge in theoretical issues or engage in ideological critique for a popular, general readership. To Link, his tack is towards specificity of context; about criticisms of Mo Yan's "daft hilarity," Laughlin explains, "Mo Yan writes about the periods he writes about because they were traumatic, not because they were hilarious," and reminds that "Mo Yan is writing primarily for a Chinese audience, not to instruct foreign readers about the tragedies of Chinese history" (Link replies that his "own worry is about the actual readers," whom he calls "numerous, mostly young, and not very well schooled in Chinese history": "How does 'daft hilarity' affect them? . . . Mo Yan's giddy treatments of history divert attention from things that are hard to look at but that still lurk in the culture at deeper levels.") ${ }^{41}$ Whereas Link's attitude toward literature seems governed by opposing what he sees as Maoism, Laughlin presents a more fluid view of how to assess literary value and morality.

Laughlin is more willing to indicate Anna Sun's prejudices, saying that by Sun's argument, "it seems doubtful that the prize could," or should, "ever go to a Chinese writer." He also notes that her framing of Mo Yan is like the Chinese Writers' Association's “line” on Gao Xingjian (高行健) (b. 1940), the naturalized French citizen who is the only other Chinese-language writer to have won the Nobel in literature: "not that his works contain politically unacceptable ideas ... [but] that Gao Xingjian is a mediocre writer." And yet, the quality of writing as such is important to Laughlin, who argues that Sun's complaint that Mo Yan writes in "a jumble of disparate linguistic 
registers" is "a strange argument to make about a twenty-first-century writer": "One thinks of the emergence of avant-garde techniques like stream of consciousness or psychological realism ... employed by authors such as Thomas Mann, Virginia Woolf, and James Joyce ..., of the landmark absurdism of a Franz Kafka, George Orwell, or Jorge Luis Borges.” Thus, while Laughlin faults Sun for finding Mo Yan "wanting" when measured "against writers of much earlier eras (Dickens, Hardy, and Faulkner)," he locates her double standard in her disqualification from "comparison to Pynchon, Rushdie, and DeLillo," say, not in that she compares him with non-Chinese writers tout court. Though it may represent a strategic dismantling of her framework, Laughlin here seems to buy into the premise of Sun's review, which is that writers can be evaluated across, rather than within or between, languages, cultures, and eras. This is the dark side to the rosy notion of being "engaged in the study of literature," quoted above; too much emphasis on "literature," as if assumptions about what makes it good or bad, moral or immoral, were the same for all periods and places, tends to de-emphasize matters of context and locality, and it opens Laughlin up to criticism from Link later.

Noting that Link does not ultimately answer the question of his title, “Does this Writer Deserve the Prize?" Laughlin writes, “The Nobel Peace Prize is not awarded for literary achievements, nor is it awarded by the same committee that awards the Nobel Prize in Literature ... In fact, it's precisely this confusion that lies at the heart of the debates about Mo Yan"42 (Link parries, "Henry Kissinger won a peace prize. If that happened, what is not possible?" Then he explains, "The title of my essay was written by editors of The New York Review of Books, and I did not see it until the piece came out"). ${ }^{43}$ But by arguing that Mo Yan "is being evaluated by the criteria of the Peace Prize ... when we should really be talking about his literary accomplishments," even as he observes that "no literature can be [apolitical]," Laughlin lines up ideologically with Chinese social discourse's recent turn to see literature as autonomous. This is what Julia Lovell calls "the uncomfortable play-off in the modern era between China, the West, and the quest for universality," which she sees in China's "quest" for a Nobel Prize in Literature; the dream of a Chinese Nobel in Literature, she writes, demonstrates China's faith "that the autonomous aesthetic can effectively resolve tensions between ... the nation and the world" even as "the often tumultuous and heavily politicized workings of this aesthetic and of the search for a Nobel Prize in twentieth-century China also point to real-world imbalances and inequalities that belie the universalistic promise of national and world literatures." ${ }^{44}$ 
Laughlin's back-and-forth on whether Mo Yan should be considered amidst and within the circulations of world literature and its broader base of ethical considerations betrays its own ideological need, popular (if dubious) amongst scholars of modern and contemporary Chinese literature, for Mo Yan's prize to be "good for [the study of]" Chinese literature - though to be sure, public debates such are this are undoubtedly beneficial for Chinese literary studies. ${ }^{45}$ Nevertheless, the tension between his two points can be reconciled, though it requires differentiating between Sun's and Link's arguments to achieve it.

\section{West-Centrism and Reading Translation}

In response to Laughlin's critique, Link faults him and others for "Westcentrism," his admittedly clumsy translation of the Chinese term he wants, “xifangzhongxinzhuyi” (西方中心主义). He sums up part of Laughlin's argument- "The world now has Woolf, Joyce, Pynchon, Rushdie, DeLillo, and others. Anna Sun apparently is lagging behind"-and then adds, "What Laughlin calls 'the world,' however, is not the world, but the West. Literary scholars in the West rail against 'hegemonism' and 'postcolonialism' but in fact practice these very things by establishing trends and then measuring the rest of the world by how well it imitates them." ${ }^{46}$ Link is not being fair to Laughlin, who also notes Mo Yan's links to the first century в.C.E. Records of the Grand Historian (史記), and "adventurous, bold, and humorous novels" such as sixteenth-century Journey to the West (西遊記) and fourteenth-century Outlaws of the Marsh (水滸傳) (sometimes translated as The Water Margin). Wanting to present himself as on her side, Link is also too polite to point out that Anna Sun's "Diseased Language" likewise falls for its own West-centrism in denigrating Mo Yan against "the great novelists ... of the human condition." He indicates his distance from her point of view, however, in asking, "Is Mo Yan really part of a flow that began with Dickens and Hardy and has now come to Faulkner and García Márquez? Why should he be? .. Why do we put him in a Western bag?"

Link stops short of proposing a "Sinocentrism" to replace or redress "West-centrism," but insofar as Sun's tactic is to strike from both sides, she puts the ills of any such centrism on display. Describing "the true legacy of Chinese literature" to which Mo Yan, in his childhood under Mao, "did not know he had been denied access," she relies on essentials: 
the splendid poetry and essays of the Tang and Song dynasties; the great novels of the Ming and Qing Dynasties; not to mention the canonical Confucian texts such as the Analects and Mencius that had long been the backbone of early education in imperial China, from the private academy of aristocratic families to the schoolrooms of rural village children. ${ }^{47}$

China's literary heritage is indeed astounding in both breadth and depth. Yet by referring to poetry of the Tang and Song, and great novels of the Ming and Qing (唐诗宋词明清小说), Sun replays the bowdlerized literary history of grade school textbooks, which overlooks, for instance, poetry of the Ming and Qing, or fiction from the Song and earlier. Laying it all on the "backbone" of Confucian texts, she latches it to what Jean-François Billeter has called China's "imperial ideology," which he explains, "What we today regard as 'Chinese civilization' ... is closely linked to imperial despotism." 48 Sun's true legacy of Chinese literature, then, is literature written by and for the small, privileged population in imperial China who were literate and had access to an education in the classics, and where "schoolrooms of rural village children" memorized Confucius and Mencius to the effect that they would be taken care of by the aristocratic families of private academies. ${ }^{49}$ Though the class politics are different, Sun's phrase "true legacy of Chinese literature" hits the same rhetorical notes as politicos and pundits do when talking about the "real America."

Sun's comparison of Mo Yan against premodern Chinese literature adheres to another ideological construction of China, which privileges the premodern over the modern. ${ }^{50}$ Of course, this is the inverse of China's own ideology; as Sun notes, in the twentieth century "the state deliberately administered a radical break with China's literary past." In large part, then, the "Western bag" to which Link refers is a bag of modern China's own fabrication. Link says as much, as well, explaining that "After the 'opening' of China in the I980s, cultural elites promoted the watchword 'walking toward the world." ${ }^{51} \mathrm{He}$ goes on to complain, however: "Westerners as well as Chinese have enjoyed and perpetuated this West-centrism. How flattering that gifted writers from that mysterious socialist country on the other side of the world see us as the literary mainstream and forefront!" But one must be quite a cultural egotist to see all moments of cultural exchange as evidence others see you as "the literary mainstream and forefront."

Link's denunciation of "West-centrism" sounds nice, because "scholars in the West rail against 'hegemonism," but does it resonate? Consider what 
Jonathan Stalling, who is both an editor of Chinese Literature Today and an associate professor of English, says about teaching Mo Yan:

Rather than reading Mo Yan's work as "magical" or "hallucinatory" realism, to avoid reading Chinese literature monoculturally in Western literary terms, I introduce my students to the Chinese philosophical ideas active in classical Chinese literary works like The Story of the Stone (also known as the Dream of the Red Chamber), in which the Buddhist notion that a phenomenon is neither real nor unreal ... gives readers a point of access to the destabilizing effect of Mo Yan's writing style. ${ }^{52}$

Stalling's colleague at Oklahoma, Robert Con Davis-Undiano, has also noted that "the Chinese novel as Mo Yan practices it" owes as much to "a well-established tradition of vernacular fiction ... with such works as The Water Margin, Journey to the West, Dream of the Red Chamber, and others" as it does to William Faulkner and Gabriel García Márquez. ${ }^{53}$ Link wonders "Why is it not quite all right for [Mo Yan's fiction] to be rooted in the storytelling tradition of his native Shandong, which itself includes flights of fancy like talking animals and aggrieved ghosts?" On the contrary, evidently it is "quite all right" indeed.

Stalling's and Davis-Undiano's cultural contextualization is based on an agenda to move past reading "monoculturally in Western terms," but is in line as well with what the author has said about his own background: in his Nobel lecture he cites Faulkner and García Márquez as inspirations, but also $\mathrm{Pu}$ Songling (蒲松齡) (1640-I715), whose tradition he says he carries on. ${ }^{54}$ Link doubts this, saying, "Writers [in the I980s] liked to claim influences from this or that famous foreign writer, even if they had read little or nothing of the foreign writer's work. Mo Yan ... says he 'was greatly inspired' by Faulkner and García Márquez, but in the next sentence says 'I had not read either of them extensively."'55 Link is quoting from Goldblatt's translation of the Nobel lecture; unaccountably, he seems not to have consulted the Chinese, in which Mo Yan says not that he hadn't read them extensively, but rather, humbly, that his “reading of them wasn't really serious" (我对他们的 阅读并不认真)..$^{56}$ Additionally, the first full-length novels by Faulkner and García Márquez to appear in Chinese translation (The Sound and the Fury and Cien años de soledad, respectively), were published in 1984, coincidentally the year Mo Yan's own publication history begins; as more of their works became available in Chinese in the years that have followed, he may have read more. ${ }^{57}$ 
Link's sense of the author function as stabilizer of meaning is so strong he can invoke it to second-guess the author's own statements about his work, but I do not bring up Mo Yan's extra-literary expressions as any kind of trump card of authorial intent. The way Mo Yan understands his own work may be relevant without being any kind of last word. Rather, the issue as I see it is about framing: Mo Yan frames his work a certain way, representing a discourse imbued with certain ideological factors, just as Stalling and Davis-Undiano and Sun and Link and Laughlin do. All discourse about literature must engage in some kind of framing, and Mo Yan, with Stalling and Davis-Undiano along with him, frame Mo Yan not nationally, and certainly not "West-centrically," but cross-culturally, transnationally, even translationally. They frame his literature as literature in the world: by mentioning premodern Chinese fiction in the same breath as American modernism and Latin American magic realism, Mo Yan indicates that his fiction translates one into the discourse of the other, merging them into an aesthetic where each becomes recognizable to the other. This marks another problem with Link's rebuke of "West-centrism": Mo Yan is not proclaiming that "he has catapulted himself through the experience of the West all the way to post-modernism," but rather that he enables the postmodern an access point into China's literary heritage, and China's premodern literary heritage an access point to postmodernity. ${ }^{58}$

Translations, of course, are another field in which ideology and discourse frame the literature in question, and as the above example about "censorship" translating "checks on the news" shows, translations from Chinese in particular are framed according to the ideological formations about the place the language originated. And yet the ideological assumptions our critics bring to Mo Yan are also evident in how they frame translation itself. Anna Sun, for instance: on the one hand, she says, "many superb Chinese writers' work does not read well in translation ... no matter how good the translator might be"; on the other hand, "the most popular work by Chinese writers in English translation today" is popular because it is too translatable - "the kind of work that has broad strokes, vivid characters, and dramatic plots, such as Mo Yan's novels." ${ }^{59}$ Rather than negating the ideology behind her presentation of Chinese literature and China, her to-and-fro on translation defines it: as Slavoj Žižek, who knows something about contradicting himself, has written, "An ideology really succeeds when even the facts which at first sight contradict it start to function as arguments in its favour." 60

Sun's argument about "translatability" and Mo Yan deserves a closer look. "Open any page," she says of Mo Yan's writing in Chinese, 
and one is treated to a jumble of words that juxtaposes rural vernacular, clichéd socialist rhetoric, and literary affectation. It is broken, profane, appalling, and artificial; it is shockingly banal. The language of Mo Yan is repetitive, predictable, coarse, and mostly devoid of aesthetic value.

And yet,

The English translations of Mo Yan's novels, especially by the excellent Howard Goldblatt, are in fact superior to the original in their aesthetic unity and sureness. The blurb for The Republic of Wine from Washington Post says: "Goldblatt's translation renders Mo Yan's shimmering poetry and brutal realism as work akin to that of Gorky and Solzhenitsyn." But in fact, only the "brutal realism" is Mo Yan's; the "shimmering poetry" comes from a brilliant translator's work.

Praising the translator, she denigrates the translator. ${ }^{61} \mathrm{Link}$, for his part, says, "Anna Sun is right." ${ }^{2}$ It can be hard, though, to compare an original with a translation; the emotional valences of style can get confused with the reader's positive or negative experiences in reading first or second languages. And style is difficult to define, which is why poems often enjoy so many translations and retranslations (for better or for worse the same has not occurred with contemporary Chinese novels in English). ${ }^{63}$

But subjective evaluations about "shockingly banal" writing or "brilliant" translations are meaningless in the absence of direct quotation (Franco Moretti's "distant reading" has picked up some currency in recent debates on world literature, but if, pace Jean-François Lyotard, we are going to be incredulous toward metanarratives, we should base our assertions not only on petits récits, but on petites lectures, as well). ${ }^{64}$ Opening "any page," then, here is a passage from Mo Yan's Hong gaoliang jiazu (红高粱家族), followed by its translation by Howard Goldblatt in Red Sorghum: A Novel of China:

有人说这个放羊的男孩是我, 我不知道是不是我。我曾对高密 东北乡极端热爱, 曾经对高密东北乡极端仇恨, 长大后努力学 习马克思主义, 我终于悟到: 高密东北乡无疑是地球上最美丽 最丑陃、最超脱现实、最圣洁最龌龊、最英雄好汉最王八蛋、 最喝酒最能爱的地方。生存在这块土地上的父老乡亲们, 喜食 高粱, 每年都大量种植。八月深秋, 无边无际的高粱红成洸洋 的血海, 高粱高密辉煌, 高粱凄婉可人, 高粱爱情激荡。秋风 苍凉, 阳光很旺, 瓦蓝的天上游荡着一朵 朵丰满的白云, 高粱 上滑动着一朵朵丰满白云的紫红色影子。一队队暗红色的人在 高粱棵子里穿梭拉网, 几十年如一日。他们杀人越货, 精忠报 
国, 他们演出过一幕 幕英勇悲壮的舞剧, 使我们这些活着的 不肖子孙相形见绌, 在进步的同时, 我真切地感到种的退化。

("Someone said that the little goatherd was me, but I don't know. I had learned to love Northeast Gaomi Township with all my heart, and to hate it with unbridled fury. I didn't realize until I'.d grown up that Northeast Gaomi Township is easily the most beautiful and most repulsive, most unusual and most common, most sacred and most corrupt, most heroic and most bastardly, hardest-drinking and hardest-loving place in the world. The people of my father's generation who lived there ate sorghum out of preference, planting as much of it as they could. In late autumn, during the eighth lunar month, vast stretches of red sorghum shimmered like a sea of blood. Tall and dense, it reeked of glory; cold and graceful, it promised enchantment; passionate and loving, it was tumultuous.

The autumn winds are cold and bleak, the sun's rays intense. White clouds, full and round, float in the tile-blue sky, casting full round purple shadows onto the sorghum fields below. Over decades that seem but a moment in time, lines of scarlet figures shuttled among the sorghum stalks to weave a vast human tapestry. They killed, they looted, and they defended their country in a valiant, stirring ballet that makes us unfilial descendants who now occupy the land pale by comparison. Surrounded by progress, I feel a nagging sense of our species' regression.” $)^{65}$

I am sure this is neither the most banal section of Mo Yan's Chinese, nor the most brilliant example of Goldblatt's English. But I do not see evidence that the "brutal realism" is Mo Yan's while the "shimmering poetry" is Goldblatt's, or that the English is superior in "aesthetic unity and sureness"; rather, this is a strong translation of an intricate passage. Goldblatt seems more willing to rely on cliché than Mo Yan (his jiduan re’ai ...jiduan chouben [极 端热爱 ...... 极端仇恨] is more “extreme love" and "extreme hatred” than "love ... with all my heart" and "hate it with unbridled fury"), and occasionally Goldblatt trips over an awkward phrase to accommodate the details of the Chinese ("ate sorghum out of preference" is more cumbersome, I think, than xishi gaoliang [喜食高粱] in expressing that people liked to, rather than were forced to, consume the grain). There is also a moment of rather loose translation, where Goldblatt takes xiao (肖) for its homophone xiao (孝) in buxiao zisun (不肖子孙); though this might accentuate what readers in English will understand as a Chinese cultural trait, it should probably be unworthy descendants rather than "unfilial descendants." But the most graceful 
moments of Goldblatt's English—“vast stretches of red sorghum shimmered like a sea of blood ... passionate and loving, it was tumultuous"; "White clouds ... float in the tile-blue sky, casting full round purple shadows onto the sorghum fields below"-are also graceful in Mo Yan's Chinese, and even where the translation is most culturally nativizing - such as "a valiant, stirring ballet"-it is only a slight step from Mo Yan's metaphor of a dance performance in Chinese, yingyong beizhuang de wuju (英勇悲壮的舞剧). Moreover, Goldblatt achieves this while representing both the style and the pacing of the source text, so that readers in English can have an appropriate sense that they are not only reading what Mo Yan has written, but how he has written, as well. ${ }^{66}$

Mo Yan's Chinese and Goldblatt's English are not identical, however. In the translation, the narrator says, "I didn't realize until I'd grown up" that Gaomi was full of contradictions. In the Chinese text, the narrator is more specific: zhangdahou nuli xuexi Makesizhuyi (长大后努力学习马克思主义) means after I had grown up and diligently studied Marxism. ${ }^{67}$ The way the English publication frames Red Sorghum as A Novel of China is an example of discursive formation in American ideology: China becomes an object of knowledge, and any reader encountering Red Sorghum will not only have simply read a story, but will finish with a greater "understanding" of China. But Cold War ideology does not relinquish control so easily when it has created an object of knowledge such as China; editing out the mention of Marxism prevents readers from understanding the importance of Marxism to China's self-definition, and the pervasiveness with which Marxist rhetoric informs China's views of itself. By relying on similar tropes of humanistic valuation and American discursive formation of China, Anna Sun does the same thing.

Mo Yan's mention of Marxism in this paragraph may be a gratuitous example of the "Mao-ti" of which Sun speaks, or how, as Link puts it, "unnoticed linguistic habits reflect conceptual approaches to the world." 68 But it may also be an example of how any given instant of discourse can work against the power implicit in larger discursive formations. Just as Faulkner's Yoknapatawpha and García Márquez's Macondo are seen as smaller versions of their authors' countries, Mo Yan says he hopes "to make tiny Northeast Gaomi Township a microcosm of China, even of the whole world" (我希望把小小的 “高密东北乡” 写成中国乃至世界的缩影一样). ${ }^{69} \mathrm{The}$ contradictions that Mo Yan's narrator claims he understands via Marxism are indeed what Marxists see as inherent to industrial development under capitalism..$^{70}$ But the narrator says he understands Gaomi to inhabit these contradictions after having studied Marxism: does this mean Gaomi still embodies the contradictions inherent to capitalism even after the Communist revolution was supposed to reconcile them? That agricultural China could 
exhibit contradictions unforeseen by Marx and unresolved by Mao? If so, then the narrator's statement that, "Surrounded by progress, I feel a nagging sense of our species' regression," takes on a fuller sense of political criticism. The contradiction between shimmering poetry and brutal realism turns out to highlight just such a counter-discursive move.

\section{The Sideways Gaze: Translational Readings}

In their responses, both Laughlin and Link refer to Mao-wenti (毛文体), or “Mao style," a term coined by Li Tuo (李陀) (b. 1939) in the eighties for the pervasive discourses of Maoism that had entered not only everyday speech but, Li Tuo claims, everyday thinking, as well. ${ }^{71}$ An essential component to "Mao style" as it appears in writings by Li Tuo and his circle, however, is how easily it has transformed from indoctrinating Chinese speakers into Maoism into a means of interpellating subjects into a neoliberal economic order. Here is noted poet Bei Dao (北島), for instance, describing the Mao-went $i$ in his essay, “Ancient Enmity” (古老的敵意):

三十年多前, 中國人生活在以“毛文體”代表的官方話語的巨大 陰影下。這種自 1949 年以來逐漸取得壟斷地位的官方話語, 幾 乎禁錮了每個人的思想方式和表達方式, 甚至戀愛方式。那年 頭, 詞語與指涉的關係幾乎都被固定化下來, 比如, “太陽”就 是毛澤東, “紅色”就是革命, “母親”就是祖國或者黨。

(Over thirty years ago, Chinese people lived under the great shadow of official discourse represented by the "Mao style." This official discourse, which had gradually become monopolistic since I949, all but shackled everyone's ways of thinking and of self-expression, even of being in love. In those years, the relationships between words and their referents were fixed, so that "the sun" was Mao Zedong, "red" was Revolution, and "Mother" was the Homeland or the Party.) $)^{72}$

This sounds like Sun's description of "Mao-ti." But Bei Dao follows this with an equally trenchant accusation of discourse current in China today: "In this internet era of so-called globalization, the new language of 'marching in step with the executioner,' though it looks on the surface to be the opposite of what we had thirty years ago, nevertheless creates a desperation that makes people feel equally powerless” (在所謂全球化的網絡時代, 這種新的“與 哈子手步調一致的”語言, 與三十年前相比, 雖表現形式相反, 但同樣 
讓人因絕望而感到無力). ${ }^{73}$ Where Sun sounds triumphant, then, or at least relieved at the emergence of the "alternative to Mao-ti literature in China" by "writers in their 20 and 30 s [whose] education took place ... when China experienced an unprecedented period of economic growth," writers and critics like Li Tuo and Bei Dao see the current discursive regime as equally threatening to creative and intellectual freedom as was the Mao style. ${ }^{74}$

The opposition Bei Dao sees between these two discourses, or between the two manifestations of the same discourse, is a struggle that he and writers like him have been facing since before Roland Barthes wrote Writing Degree Zero: namely, how can we write literature that stands in opposition both to the discursive dictatorship of the bourgeoisie and the discursive dictatorship of socialist realism? For all that critics have tried, since before his exile from the People's Republic of China, to label Bei Dao a "dissident" and conscript him into a fight over universalist notions of literary value, his writing shows one attempt to write at degree zero where, as Barthes puts it, "the noun can live without its article ... pregnant with all the past and future specifications." ${ }^{\prime 5}$

Mo Yan is not Bei Dao, and his writing does not seem to be as at odds with either discursive domination as Bei Dao's. But the burden of political engagement with discourses is not only on the writer. Publishers have a responsibility, as well, which is what Christopher Mattison points out when he faults editors for "focusing on 'dissidence' rather than 'dissonance," but ultimately the role of finding the right politics of literature amidst the dissonance of discourses falls to the reader. ${ }^{76}$ Interestingly, Roland Barthes here can offer another tactic. In his journal of his trip to Cultural Revolution China in 1974, Barthes mentions a binary of approaches to understanding China: there are those, he writes, who make "an intent and constant effort to speak about China from the point of view of China; a gaze coming from the inside," and then there is the insistence on seeing "China from the point of view of the West." My attempt here has been to write against the latter point of view without adopting the former, for as Barthes says, "These two gazes are, for me, wrong. The right gaze is a sideways gaze."

Simply positing a "sideways gaze" as "the right gaze" is insufficient on its own; moreover, for all that this example represents an encounter between literary theory and Chinese reality, relying on Barthes here may be to succumb to what Link calls the latest Western hegemonism in the name of a modish anti-hegemonism. Viewing China and its cultural products from the perspective of only the West or only China (or, more probably for those of us working in English, a China imagined through its a priori construction by Western discourse with which it must contrast, such as Sun's 
proclamation of "the true legacy of Chinese literature" or Link's opposition to the "Western bag" of "Faulkner and García Márquez" because the author "says" he had not "read" them "extensively") is clearly too limited for accounts of these products' circulation around and within the world. In and of itself, however, saying "sideways gaze" does nothing to ensure that the reader's gaze won't remain as ideologically predetermined as ever under the cover of a sideways appellation. A more specific itinerary in order, then, my particular attempt for a sideways gaze has been to read, to reuse a term I put forth above, translationally. Just as Mo Yan's fiction can be an access point between global postmodernity and China's literary heritage, a translational reading may approach a text - both before and after it has been translated - as a kind of translation, through which not only can the reader access its source and target cultures, but through which source and target cultures can access each other, as well. A translational reading that pays attention to source and target cultural contexts, and to the role of the translator and how a text may be shaped by the needs or interests of a range of powers in those contexts, can see ideology and discourse at work even as it derives its main legitimacy from detailed attention to the text (translation is ultimately textual, after all). By constantly shifting its own point of view, a translational reading can remain fluid, seeing and at times reconciling but not speaking from the perspective of any stable global position; in this way it can remain sideways. Around such moments of literature in the world as provided by the Nobel Prize, a translational methodology becomes all the more possible and necessary.

In the struggle between discourses, and in reading literature from around the world which responds to, ingests, and opposes a multitude of discourses, the reader becomes the judge of the political value of the writing in question. Inverting the Cold War mode of literary politics, then, in which the goings-on in Peking were understood as a literary text whose job the China watcher's was to decode, we can now reach a political literacy, in which the reader, with the translational sideways gaze, can turn the reading of literature into an act of political resistance. Rather than asking if Chinese writers can "speak truth to power," we may want to try, instead, to translate power through our readings.

LUCAS KLEIN is translating Tang dynasty poet Li Shangyin and seminal contemporary poet Mang Ke. His work has appeared in Jacket, Rain Taxi, $C L E A R$, and PMLA, and from Fordham, Black Widow, and New Directions. An Assistant Professor at HKU, his translation of Xi Chuan won the 2013 Lucien Stryk Prize. 
Notes

I. Perry Link, "Review of Chinese Reportage: The Aesthetics of Historical Experience. By Charles A. Laughlin," The China Quarterly I79 (2004): 846-47, doi:Io.IoI7/So30574Io044Io6or. See Charles Laughlin, Chinese Reportage: The Aesthetics of Historical Experience, Asia-Pacific: Culture, Politics, and Society (Durham: Duke University Press, 2002).

2. Charles Laughlin, "Laughlin Response to Link Review," email, MCLC List (Nov. 6, 2004). For Link's complaint against theory, Laughlin cites Perry Link, "Ideology and Theory in the Study of Modern Chinese Literature: An Introduction," Modern China I9, no. I (I993): $4^{-\mathrm{I} 2 .}$

3. See Paul de Man, "The Resistance to Theory," in The Resistance to Theory, Theory and History of Literature 33 (Minneapolis: University of Minnesota Press, I986), 3-20.

4. See Terry Eagleton, After Theory (London; New York: Allen Lane, 2003) and Terry Eagleton, Literary Theory: An Introduction, 2nd ed. (Minneapolis: University of Minnesota Press, 1996).

5. Jonathan D. Culler, Literary Theory: A Very Short Introduction (Very Short Introductions 4), 2nd ed., (Oxford: Oxford University Press, 20II).

6. See William K. Wimsatt and Monroe C. Beardsley, "The Intentional Fallacy," The Verbal Icon: Studies in the Meaning of Poetry (Lexington: University of Kentucky Press, 1954), 3-18 and Roland Barthes, "The Death of the Author," Image-Music-Text (Fontana Communication Series), trans. Stephen Heath (London: Fotana/Collins, 1977), I42-48.

7. Michel Foucault, "What Is an Author?," The Foucault Reader, ed. Paul Rabinow, trans. Josué V. Harari (New York: Pantheon Books, I984), IoI-20.

8. Jacques Derrida, De la grammatologie (Paris: Les Editions de Minuit, 1967), 227. I cite Derrida in French because Gayatri Spivak's translation as "there is nothing outside the text" seems in this instance incorrect (Jacques Derrida, OfGrammatology, trans. Gayatri Chakravorty Spivak, corrected ed. [Baltimore: Johns Hopkins University Press, 1998], I63.).

9. Perry Link, An Anatomy of Chinese: Rhythm, Metaphor, Politics (Cambridge: Harvard University Press, 2013), Io9.

Io. For examples, see criticisms by 2009 Nobel Literature laureate Herta Müller (AAP, "Fellow Laureate Excoriates Nobel Winner," The Australian, accessed Nov. 29, 2012, http:// www.theaustralian.com.au/news/breaking-news/fellow-laureate-excoriates-nobel-winner/ story-fn3dxix6-I226523625253 and Associated Press, "Nobel Literature Winner Herta Mueller Calls 2012 Choice of China's Mo Yan a 'Catastrophe," StarTribune, Nov. 24, 20I2, http://www .startribune.com/entertainment/celebrities/18068907r.html); Chinese artist Ai Weiwei (艾未末) (Nick Clark and Clifford Coonan, "Ai Weiwei Brands Nobel Prize for Literature Decision an 'Insult to Humanity' as China's Mo Yan Named Winner," The Independent, Oct. II, 20I2, http:// www.independent.co.uk/arts-entertainment/books/news/ai-weiwei-brands-nobel-prize-forliterature-decision-an-insult-to-humanity-as-chinas-mo-yan-named-winner-82071og.html); and journalist Didi Kirsten Tatlow ("The Writer, the State and the Nobel," IHT Rendezvous, Oct. I2, 20I2, http://rendezvous.blogs.nytimes.com/20I2/ro/r2/the-writer-the-state-and-thenobel/). For defenses, see comments by Michel Hockx of the School of Oriental and African Studies (Alison Flood, "Mo Yan Wins Nobel Prize in Literature 2012," The Guardian, Oct. II, 20I2, http://www.guardian.co.uk/books/20I2/oct/ri/mo-yan-nobel-prize-literature; Clark and Coonan, "Ai Weiwei Brands Nobel Prize for Literature Decision an 'Insult to Humanity' as China's Mo Yan Named Winner"); Jonathan Stalling ("Mo Yan and the Technicians of Culture," World Literature Today, Oct. 29, 2012, http://www.worldliteraturetoday.com/mo-yan-andtechnicians-culture\#.ULS50NcazSh); Pankaj Mishra ("Why Salman Rushdie Should Pause before Condemning Mo Yan on Censorship," The Guardian Dec. 13, 20I2, sec. Books, http:// www.theguardian.com/books/20I2/dec/13/mo-yan-salman-rushdie-censorship?fb=optOut; and Kamila Shamsie and Pankaj Mishra, "Where's The Rage?," Guernica: A Magazine of Art E̋ Politics, Feb. 3, 20I4, http://www.guernicamag.com/interviews/wheres-the-rage/). For long review articles that engage with some of the terms of the controversy, see Sabina Knight for the defense and Nikil Saval for the prosecution (Sabina Knight, "Mo Yan's Delicate Balancing 
Act," The National Interest, Apr. 2013, http://nationalinterest.org/bookreview/mo-yans-delicatebalancing-act-8162?page=show and Nikil Saval, "White Happy Doves," London Review of Books, Aug. 29, 2013). After the naming of Alice Munro as 2013's Nobel laureate, Max Fisher wrote, "Dissident writer Alice Munro awarded Nobel for fiction critical of Canadian regime," which is "a satirical take on the story you might be reading if Munro were from an authoritarian, developing country such as China" (Max Fisher, "Dissident Writer Alice Munro Awarded Nobel for Fiction Critical of Canadian Regime," Washington Post, Oct. Io, 2013, http://www .washingtonpost.com/blogs/worldviews/wp/2013/ro/ıo/dissident-writer-alice-munro-awardednobel-for-fiction-critical-of-canadian-regime/); of course, as some commentators noted, differences between how Canadian and Chinese regimes treat political opposition also accounts for how the press reports on China.

II. David Daley, "Rushdie: Mo Yan Is a 'Patsy of the Regime," accessed Apr. 2, 20I3, http:// www.salon.com/20I2/ı2/o7/rushdie_mo_yan_is_a_patsy_of_the_regime/.

I2. Eliot Weinberger, "The Month of Rushdies," Outside Stories, 1987-1991 (New York: New Directions, 1992), 92, II5. See also Daniel Pipes, The Rushdie Affair: The Novel, the Ayatollah, and the West (Seacaucus: Carol Publishing Group, 1990), 115-17.

I3. Salman Rushdie, "Satanic View That Equates Democracies and Dictatorships," The Guardian, Dec. I6, 20I2, sec. Books, http://www.guardian.co.uk/books/2012/dec/ı6/ satanic-view-democracies-dictatorships?CMP=twt_gu.

I4. Brendan O'Kane, "Is Mo Yan a Stooge for the Chinese Government?," Rectified.name (正名), accessed Nov. 27, 2012, http://www.rectified.name/2012/10/15/ is-mo-yan-a-stooge-for-the-chinese-government/.

15. In fairness, Salman Rushdie has written that "Naipaul makes himself a fellow traveller of fascism and disgraces the Nobel award" for supporting Hindu nationalists in India (Salman Rushdie, "Religion, as Ever, Is the Poison in India's Blood," The Guardian, Mar. 9, 2002, sec. Books, http://www.guardian.co.uk/books/2002/mar/og/society.salmanrushdie).

I6. Associated Press, "Censorship Is a Must, Says China's Nobel Winner," The Guardian, Dec. 7, 20I2, http://www.guardian.co.uk/world/20I2/dec/o7/mo-yan-censorship-nobel.

I7. Yiyun Li, "Pow! by Mo Yan-Review," The Guardian, Jan. I8, 20I3, sec. Books, http:// www.guardian.co.uk/books/2013/jan/r8/pow-mo-yan-review?CMP=twt_gu and Mo Yan, Mo Yan Ruidian Nuobei'er jiang xinwen fabuhui (莫言瑞典诺奖新闻发布会) [Nobel Prize Press Conference with Mo Yan in Sweden], Dec. 6, 20I2, http://www.kouyi.org/press/1928.html.

I8. "Banned Chinese Writers," Words Without Borders, Nov. 20I2, http://wordswithoutborders. org/issue/november-2oI2.

I9. Mo Yan, "Storytellers: The Nobel Lecture," trans. Howard Goldblatt, Dec. 7, 20I2, http:// www.nobelprize.org/nobel_prizes/literature/laureates/20I2/yan-lecture_en.html.

20. Anna Sun, "The Diseased Language of Mo Yan," Kenyon Review Online, Fall 2012, http:// www.kenyonreview.org/kr-online-issue/20I2-fall/selections/anna-sun-656342/.

2I. Because the articles in question by Sun, Link, and Laughlin appeared online and without page numbers, I will forego citing each individual quotation when its source is clear.

22. Sun uses traditional characters (fantizi [繁體字]) rather than simplified characters (jiantizi [简体字]) to represent terms and names in Chinese. Because most of the names and terms refer to people and concepts whose lives are mostly defined in relation with mainland China, I will tend toward simplified characters here, but will use traditional characters to quote from Taiwan or Hong Kong publications, or for names and titles from before mainland China's character reform movement of the late mid-twentieth century.

23. Anna Sun, "Mao-Ti," London Review of Books, July 8, 2004, I2.

24. Sun, "Diseased."

25. Michel Foucault, The History of Sexuality: An Introduction, trans. Robert Hurley, 5 th or Later ed. (New York: Vintage Books, 1990), , oo. For her website, see Anna Sun, "Personal Website," Feb. 20I2, http://personal.kenyon.edu/suna/.

26. Vladimir Il'ich Lenin, The State and Revolution: Marxist Teaching on the State and the Tasks of the Proletariat in the Revolution, trans. unnamed (Beijing: Foreign Languages Press, 1973), ${ }_{5}$ I. 
27. Hong Zicheng (洪子诚), A History of Contemporary Chinese Literature, trans. Michael Martin Day (Leiden: Brill, 2007), 28.

28. For details on the structure of the CWA, see Perry Link, The Uses of Literature: Life in the Socialist Chinese Literary System (Princeton: Princeton University Press, 2000), II8-22. Whatever its benefits and limitations, the CWA seems to have become less important to professional literary figures in China.

29. Tatlow, "The Writer, the State and the Nobel." For the Chinese, see Zhang Zhongjiang (张中江), "Mo Yan: Yixie Zuojia Na Gongzi Xiangshou Fuli Zhe Shi Zhongguo Xianshi" (莫言: 一些作家拿工资享受福利 这是中国现实) [“Mo Yan: Some Writers Get Salary and Benefits This Is the Reality in China"], Chinanews.com, Dec. I6, 2009, http://www.chinanews .com/cul/news/2009/12-16/202I204.shtml.

30. Louis Althusser, "Ideology and Ideological State Apparatuses (Notes towards an Investigation)," in Lenin and Philosophy and Other Essays, trans. Ben Brewster (New York: Monthly Review Press, 200I), I27-87.

31. Eliot Weinberger, "James Jesus Angleton 1917-1987," Outside Stories, 1987-1991 (New York: New Directions, 1992), 53 .

32. James Peck, "The Roots of Rhetoric: The Professional Ideology of America's China Watchers," in America's Asia: Dissenting Essays on Asian-American Relations (Pantheon Antitextbooks), eds. Edward Friedman and Mark Selden, (New York: Pantheon Books, 197I), 4I, 40; quoting George Kennan, "A Fresh Look at Our China Policy," New York Times Magazine, Nov. 22, 1964, 27.

33. Sun, "Diseased."

34. In her review of Flora Drew's translation of The Noodle Maker by Ma Jian (马建) (b. 1953), Sun mentions her upbringing in the PRC during the seventies and eighties.

35. Mo Yan was one of a hundred Chinese writers to transcribe by hand passages from Mao's “Talks" for a seventieth anniversary commemorative edition (Liu Xiangnan [刘向南], "Mo Yan: Shouchao Mao Zedong Zai Yan'an Wenyi Zuotan Hui Shang de Jianghua” [莫 言：手抄毛泽东在延安文艺座谈会上的讲话] [Mo Yan:Transcribing Mao Zedong's Yan'an Talks on Literature and Art], Zhongguo Shuzi Shidai [中国数字时代] [China Digital Times], accessed Apr. IO, 20I3, http://chinadigitaltimes.net/chinese/20I2/ro/莫言 墨迹: - 手抄毛泽 东在延安文艺座谈会上的讲话 /). Even Mo Yan's English-language defenders criticize this (see Charles Laughlin, "Mo Yan's Nobel Prize for Literature: Resetting Chinese Literature" (University of Virginia, Mar. I, 2013), http://www.broadcastforfriends.com/video/13516553; O'Kane, "Stooge?"; and Howard Goldblatt and Joseph Roe Allen, "A Conversation with Howard Goldblatt" (University of Minnesota, Nov. 27, 20I2), http://ias.umn.edu/20I2/rI/26/ goldblatt-howard/). But Mo Yan's public adoption of the implicit politics of claiming literature to be apolitical - that literature should "not just originate in events, but transcend them, not just show concern for politics but be greater than politics” (发端事件但超越事件, 关心 政治但大于政治) (“Storytellers”)—accords with the Swedish Academy's recent manner of upholding Alfred Nobel's directive to honor "in the field of literature the most outstanding work in an ideal direction" ("The Nobel Prize in Literature," Nobelprize.org, accessed Apr. Io, 2013, http://www.nobelprize.org/nobel_prizes/literature/).

36. Link, "Ideology and Theory," 9.

37. Perry Link, "Does This Writer Deserve the Prize?," The New York Review of Books, Dec. 6, 2012, http://www.nybooks.com/articles/archives/2012/dec/o6/ mo-yan-nobel-prize/?pagination=false.

38. Link, The Uses of Literature, 294. The overarching thesis of that book is that "the variety of literary uses in socialist China was greater than we have yet recognized. Each of the 'social-document,' 'literary-dissent,' and 'artistic-quality' approaches has been by itself too narrow a lens to capture the entire variety" (I2).

39. Compare this with Larry Siems and Jeffrey Yang, "China's Nobels," The New York Times, Oct. I7, 20I2, sec. Opinion, http://www.nytimes.com/20I2/ro/r8/opinion/chinas-nobels.html. While Yang, the translator of Liu Xiaobo's June Fourth Elegies (trans. Jeffrey Yang, Lannan Translation Selection [Minneapolis: Graywolf Press, 20I2]), takes solace in Mo Yan's recognition 
of the imprisoned dissident, Link, editor of Liu's No Enemies, No Hatred: Selected Essays and Poems (Perry Link, Tienchi Martin-Liao, and Liu Xia [刘霞], eds., [Cambridge: Belknap Press of Harvard University Press, 20I2]), is less impressed. Link cites Chinese citizens' tweets that "if Mo Yan has guts, he will stand next to an empty chair when he speaks in Stockholm"; translator A. E. Clark reads the "empty chair" anecdote in Mo Yan's speech as an allusion to Liu Xiaobo ("Mo Yan's Middle Finger," RaggedBanner.com, Dec. I4, 20I2, http://www.raggedbanner.com/ Editorials/MoYanFinger.html).

40. Perry Link, "Politics and the Chinese Language:What Mo Yan's Defenders Get Wrong," Chinafile.com, Dec. 24, 20I2, http://www.chinafile.com/politics-and-chinese-language.

4I. Charles Laughlin, "What Mo Yan's Detractors Get Wrong," ChinaFile, Dec. II, 2or2, http://www.chinafile.com/what-mo-yan\% $\mathrm{E}_{2} \% 80 \% 99$ s-detractors-get-wrong and Link, "Politics and Chinese."

42. Laughlin, "Detractors."

43. Link, "Politics and Chinese." Laughlin also mentions that he had wanted his article to be called "In Defense of 'Diseased Language," but that the editors re-titled it "Resetting Chinese Literature."

44. Julia Lovell, The Politics of Cultural Capital: China's Quest for a Nobel Prize in Literature (Honolulu: University of Hawai'i Press, 2006), I8.

45. The dubiousness can be demonstrated by analogy: Was Tomas Tranströmer's prize good for the study of Swedish literature? Was Orhan Pamuk's good for Turkish or Imre Kertész's for Hungarian? Did more people study American literature because of Toni Morrison's win?

46. Link, "Politics and Chinese." I think he means "neo-colonialism." At any rate, Link's argument about "West-centrism" leads to the ethics of "West-centric condescension": "When I give public lectures on human rights in China, I very often get questions from audiences that ask, one way or another, 'Why are you criticizing the Chinese government when our own government is so bad?'; while I agree, and do not wish to critique that aspect of his argument, I note in passing his phrase "double standards in Western attitudes," since he seems to share responsibility in the spreading of those double standards. For more on the problems of "lagging behind" or being "behind the times," see Eric Hayot, "Chinese Modernism, Mimetic Desire, and European Time," The Oxford Handbook of Global Modernisms, ed. Mark A. Wollaeger and Matt Eatough (New York: Oxford University Press, 20I2), I49-70.

47. Sun, "Diseased."

48. Jean-François Billeter, Contre François Jullien [Against François Jullien] (Paris: Allia, 2006), as quoted in Henry Zhao, "Contesting Confucius," New Left Review 44 (Apr. 2007): 138.

49. While Confucianism is unarguably elitist, my point is not to imply that this applies to the entire tradition of Chinese written culture. On the contrary, the tradition is too broad to be described so simply, which is what I see Sun doing here. And while the record of imperial examinations provides plenty of examples of children of poor backgrounds ascending, through their mastery of the classics, to positions of power (Zhang Juzheng [張居正] [1525-I582] Grand Secretary of the Ming dynasty, comes to mind; see Ray Huang, 1587, a Year of No Significance: The Ming Dynasty in Decline [New Haven: Yale University Press, 198r]), there is no question that, like any purported meritocracy, it included its own ingrained reiterations of power.

50. Another example of this is her endorsement of Stephen Owen's "controversial claim ... that certain contemporary Chinese poetry is written in easily translatable language, instead of seeking mastery in original Chinese" (Stephen Owen, "What Is World Poetry? The Anxiety of Global Influence," New Republic 203, no. 2I (Nov. 19, 1990): 28-32). But while Owen mentions that the "international audience" is "hungry for political virtue," he also mentions that "Chinese readers of 'new poetry' ... tend to admire Bei Dao's earlier, more engaged political poetry, and they tend to deplore his turn away from politics to more private concerns" (3I); in contrast with Sun's citation, then, Owen sees the possibility of restoring a modicum of "Chineseness" against incursions of "world poetry" and its cultural hegemony in writing a literature engagé with political concerns.

51. Link, "Politics and Chinese."

52. Stalling, "Mo Yan and the Technicians of Culture." 
53. Robert Con Davis-Undiano, "A Westerner's Reflection on Mo Yan," World Literature Today, Oct. I2, 20I2, http://www.worldliteraturetoday.com/westerners-reflection-mo-yan\#. ULcbr-_heSo.

54. Mo Yan, "Storytellers."

55. Link, "Politics and Chinese."

56. Mo Yan, “Jiang Gushi de Ren" (讲故事的人) [“Storytellers: The Nobel Lecture”], Dec. 7, 20I2, http://www.nobelprize.org/nobel_prizes/literature/laureates/2or2/yan-lecture_ki.pdf. Likewise, in "White Happy Doves” Nikil Saval picks up on Mo Yan's admission, in Goldblatt's translation, of having read "read little of their work" whereas the phrase in Chinese is 我没有 很好地去读他们的书: “I didn't read their books very well.”

57. Zha Mingjian (查明建) and Xie Tianzhen (谢天振), Zhongguo 20 Shiji Waiguo Wenxue Fanyi Shi (中国20世纪外国文学翻译史) [A History of the 20th Century Foreign Literary Translation in China], Zhonghua Fanyi Yanjiu Congshu 4 (Wuhan: Hubei jiaoyu chubanshe, 2007), 99I-93, I32I-24. Zha and Xie list nearly twenty short stories of Faulkner's to see journal publication in Chinese from the thirties to 1983 , but since I count one hundred of his short stories to have been published in English during his lifetime (and another twenty-six since), Mo Yan could have read everything of Faulkner's available in Chinese and still claim not to have read Faulkner extensively.

58. Link, "Politics and Chinese."

59. Sun, "Diseased."

6o. Slavoj Žižek, The Sublime Object of Ideology, 2nd ed. (London: Verso, 2009), 50.

6r. In her Ma Jian review, Sun offers a similar backhanded compliment: "Flora Drew's translation of The Noodle Maker is more graceful than the original, lacking the self-conscious rudeness of the Chinese and the uneasy kinship with the Maoist style" (Sun, "Mao-Ti," I2).

62. Link, "Politics and Chinese."

63. Although, see Adam Thirlwell, ed., Multiples: 12 Stories in 18 Languages by 61 Authors (London: Portobello Books Limited, 2013).

64. Franco Moretti, "Conjectures on World Literature," in Debating World Literature, ed. Christopher Prendergast (London: Verso, 2004), I48-62 and Jean-François Lyotard, The Postmodern Condition: A Report on Knowledge, trans. Geoffrey Bennington and Brian Massumi, Theory and History of Literature v.Io (Manchester: Manchester University Press, 1984), 3.

65. Mo Yan, Hong Gaoliang Jiazu (红高粱家族) [Red Sorghum Clan] (Beijing: Jiefangjun wenyi chubanshe, 1987), 2 and Mo Yan, Red Sorghum: A Novel of China, trans. Howard Goldblatt (Penguin Books, 1994), 4.

66. I am here following the method of "syntactic tracking" as laid out in Burton Raffel, The Art of Translating Prose (University Park: Pennsylvania State University Press, 1994).

67. Interestingly, this phrase itself has disappeared and reappeared in various versions in Chinese, as well. While the reference to studying Marxism appears in the first full-length publication, cited above (Beijing, 1987), it does not appear in the 1988 Taiwan edition (Taipei: Hongfan shudian, 1988) from which Goldblatt based his translation, at "the request of the author," to restore "cuts made in the Mainland Chinese edition" (Red Sorghum, r; Goldblatt adds, "Some deletions have been made, with the author's approval"). Cold War knowledge production vis-à-vis the mainland has certainly had its effect in Taiwan, but in the 2007 Taiwanese reprint, the reference to Marxism has been reinstated (Taipei: Hongfan shudian, 2007).

68. Link, "Politics and Chinese."

69. Mo Yan, "Storytellers."

70. While Gaomi seems an unlikely example of "industrial development," this passage, as a student pointed out, echoes the beginning of $A$ Tale of Two Cities, from "It was the best of times, it was the worst of times" (Charles Dickens [London: Chapman \& Hall, I898], 23).

7I. Link calls it "Mao-language"; Laughlin refers to it as the strangely corporate-sounding “MaoSpeak”; Link cites Li Tuo (李陀), “Ding Ling Bu Jiandan: Mao Tizhi Xia Zhishifenzi Zai Huayu Shengchan Zhong de Fuza Juese” (丁玲不簡單: 毛體制下知識分子在話語生産中 的複雜角色) [“Ding Ling's Not So Simple: The Complex Role of Intellectuals in Discursive Production Under Mao"], Jintian (今天) [Today] 22 (1993): 222-42. For applications of the 
term that have appeared in English, see Li Tuo, “The New Vitality of Modern Chinese," Inside Out: Modernism and Postmodernism in Chinese Literary Culture, ed. Wendy Larson and Anne Wedell-Wedellsborg (Aarhus: Aarhus University Press, 1993), 65-77 and Li Tuo, "Resisting Writing," in Politics, Ideology, and Literary Discourse in Modern China: Theoretical Interventions and Cultural Critique, ed. Kang Liu and Xiaobing Tang, trans. Mary Scoggin (Durham: Duke University Press, I993), 273-77.

72. Bei Dao (北島), “Gulao de Diyi” (古老的敵意) [“An Ancient Enmity”], in Gulao de Diyi (古老的敵意) [An Ancient Enmity] (Hong Kong: Oxford University Press, 2012), I52. Translation my own. Compare Fiona Sze-Lorrain, trans., "Ancient Enmity," Mānoa 24, no. I (2OI2): I-5.

73. Bei Dao, "Gulao de Diyi," 152-53.

74. Sun, "Diseased."

75. Roland Barthes, Writing Degree Zero, trans. Annette Lavers and Colin Smith (London: Cape, 1967), 48.

76. Christopher Mattison and Greta Aart, "Entering Another Literature: Christopher Mattison on Russian, Chinese, and Hong Kong Literature in Translation," Cerise Press: A Journal of Literature, Arts \& Culture, Fall/Winter 20I2, http://www.cerisepress.com/o4/II/ entering-another-literature-christopher-mattison/view-all.

77. Roland Barthes, Travels in China, ed. Anne Herschberg-Pierrot, trans. Andrew Brown (Cambridge: Polity Press, 20I2), I77. For a helpful synopsis, see Dora Zhang, "The Sideways Gaze: Roland Barthes's Travels in China," Los Angeles Review of Books, June 23, 2012, http:// lareviewofbooks.org/essay/the-sideways-gaze-roland-barthess-travels-in-china/. 